Society's native ministers at Mauke seems charmingly naïve. And his approval of their modesty in being "muffled closely" and wearing a length of kapa around their shoulders "in the same manner that an English lady would wear her shawl" indicates a gentle prudery typical of his times.

Perhaps the historian might regret the the lack of political analysis by Dampier. He attended a council of chiefs in Honolulu called to meet with Lord Byron to discuss "the state of the nation." He was in Chile when the new nation was attempting, not too successfully, to achieve political stability and he met many of the important leaders of the time. Yet political discussion in either area occupied his interest hardly at all. The battle he witnessed at Callao and the news of a war in Hawaii were fully recorded. But apparently he was indifferent to the complexities and subtleties of politics.

Perhaps this preference for nature and society in their visible manifestations gives the Dampier journal its special charm. To see the eastern Pacific with his youthful enthusiasm and his artist's sensitivity is to see the area in a most pleasurable form.

The journal published here was made available to the University of Hawaii Press by Lieutenant Commander Denis Dampier, Royal Navy (retired), of West Clandon, Surrey, England, who also supplied the biographical material. The journal had been presented to the artist's daughter, Matilda Elizabeth, and passed next to her nephew, Admiral Cecil F. Dampier, Royal Navy, grandson of Robert, and father of Denis. The present publication includes reproductions of thirty sketches which are part of the journal and of four portraits and two seascapes which are in collections in Hawaii. The copies of the portraits of Nahi'ena'ena and Kauikeaouli were made available through the courtesy of the Honolulu Academy of Arts. The Office of the Governor of the State of Hawaii granted permission for the inclusion of the copies of the portraits of the young chief and chiefess and the views of the Blonde at sea. The map on page vi detailing the track of H.M.S. Blonde was taken from the Voyage of H.M.S. Blonde to the Sandwich Islands in the Years $1824-1825$.
Biographical Note

Robert Dampier was born in 1800 at Colford St. Peter's in Wiltshire, one of thirteen surviving children of the Reverend John Dampier. His forebears probably came from Flanders in the fifteenth century and settled in Lincolnshire in pursuit of some occupation in connection with the wool trade. They became prosperous merchants, property owners, and public officials in Lincolnshire. His grandfather, John, served as mayor of Wareham on four occasions between 1774 and $\mathbf{I} 795$. His father took holy orders after leaving Oxford and began an association with the Church of England that remains a tradition to the present day.

The most well-known Dampier, William (1652-1715), buccaneer, captain in the British Navy, and circumnavigator, may have been of the same family stock as the diarist, but the relationship seems to be remote. William was a frequent visitor at the Galápagos Islands in the late seventeenth century. At that time Pacific buccaneers used the islands as a base for their raids against Spanish treasure ships. It is at least an interesting coincidence that two Dampiers were visitors to that strange and rarely visited region.

Robert left England in 1818 to become a clerk in the establishment of his brother-in-law, William May, a wealthy merchant in Rio de Janeiro. It was there, six years later, that the artist met Lord Byron. How he became acquainted with Byron can only be surmised. There is evidence that Byron knew of him and his family through acquaintances in the Navy. Perhaps, also, the artist's proficiency was well known in Rio. What is apparent is that the young man was given a preferred position on board the Blonde.

Upon his return to England, Dampier attended Cambridge University, first at Christ's College then at Corpus Christi College. By 1836 he had acquired a law degree and had also taken holy orders. Although he had charge of a country parish early in his career and again during the last years of his life, he spent most of his time traveling in Europe, or residing at his homes in Le Havre, France, or Guernsey, in the Channel Islands. In the words of his great-grandson, Denis, "One gets the impression ... of a ... man who lived in the spacious days when it was possible for a clergyman of private means to travel extensively and to devote much of his time to his leisure pursuits. 
Not much is known of his life abroad but there seems to be a good deal of evidence that he spent as much of his time in painting as he did in preaching."

In 1828 Robert married Sophia, daughter of Colonel Elliott Roberts. There were four children: Frederick, who became chief magistrate of Georgetown, Demerara, British Guyana; Augustus, who took holy orders; Juliana, who married Sir William Robinson, governor of, at various times, the Bahamas, Barbados, Trinidad, and Hong Kong; and Matilda Elizabeth, who remained single. Dampier's first wife died in 1864 , and he married again in 1872 . A daughter, Frederika, was the only child of this marriage, and she remained single. The voyager-diarist-artist-clergyman died in 1874 .

\section{Published Accounts of the Blonde's Voyage}

There are at present three published accounts relating to the voyage of the Blonde. The earliest is the Voyage of H.M.S. Blonde to the Sandwich Islands in the Years $1824-1825$, published in London in 1826 . The work is a compilation of information gathered from diaries of various members of the expedition, in particular that of the Reverend Richard Bloxam, chaplain on board. Several of Dampier's sketches are included. Mrs. Maria Graham edited the book, and soon after its publication it was criticized in London as containing "flagrant inaccuracies." The fact that the work is a compilation limits its usefulness.

In 1922 those parts of the diary of James Macrae, botanist, specifically relating to the Hawaiian Islands were published in Honolulu. Macrae sailed on the Blonde at the request of the Horticultural Society of London, now the Royal Horticultural Society, with a collection of plants to be distributed in Hawaii. He had also been directed to collect plant specimens for the Society. Some incidents described by Macrae are found in the Dampier journal.

In 1925 the portions of Andrew Bloxam's diary relating to the Hawaiian Islands were printed in full by the Bernice P. Bishop Museum, and excerpts from the rest of the diary, interspersed with editorial comment, preceded and followed the quoted portion. Andrew, brother of the chaplain, Richard, was the naturalist on the Blonde. His short description of the visit to the temple at Honaunau contrasts sharply with Dampier's.

The present journal is the only one so far published that describes the entire voyage from the point of view of a single participant.

Note on the Spelling

American Protestant missionaries who arrived in Hawaii in 1820 began to put the Hawaiian language into a written form, and by January of 1822 an alphabet had been standardized. Material was being printed in the language and the final alphabet was produced in 1826 .

Westerners had had difficulty in writing down the Hawaiian words they heard. For example, they often mistook the case sign attached to a proper name as part of the name. Atooi is a compound of two words, a Tauai which mean "and Tauai," the island of Tauai, or Kauai. Similarly, the $o$ of Owhyhee is the sign of the nominative case of Whyhee, or Hawaii.

Vowel distinctions and variations of pronunciation also presented problems. The Reverend William Ellis, an expert in the Tahitian and Hawaiian languages, pointed out that there were no counterparts in English for certain Hawaiian vowel sounds, and some letters were interchangeable. Thus Tauai became Kauai in some regions; Karaimoku became Kalaimoku.

Dampier's spelling exemplifies a transitional stage. $\mathrm{He}$ arrived in Hawaii in 1825 , after some Hawaiian had been printed but before the alphabet was settled upon. Hence his spelling shows only moderate variations. The form has been kept as it appeared in the diary, and variations are noted in the text.

The English usage of the early nineteenth century as reflected in Dampier's spelling and punctuation has been retained. Obvious misspellings have for the most part been corrected, however, the idiosyncrasies of Dampier's spelling have been kept. His practice of underlining words, not related to the modern practice of underlining for emphasis, has not been followed. 